\title{
How do demersal fishing fleets interact with aggregate extraction in a congested sea?
}

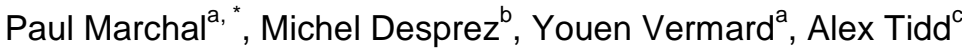

\author{
a IFREMER, Channel and North Sea Fisheries Department, 150 Quai Gambetta, BP 699, 62321 Boulogne s/mer, \\ France \\ ${ }^{\mathrm{b}}$ University of Rouen, UMR 6143 - Morphodynamique Continentale et Côtière, Place Emile Blondel, 76821 Mont \\ Saint Aignan Cedex, France \\ ${ }^{c}$ CEFAS, Pakefield Road, Lowestoft, Suffolk NR33 OHT, United Kingdom
}

\author{
*: Corresponding author : Paul Marchal, email address : paul.marchal@ifremer.fr \\ despzmike@wanadoo.fr ; youen.vermard@ifremer.fr ; alex.tidd@cefas.co.uk
}

\begin{abstract}
:
The effects of the aggregate extraction intensity and the distance to extraction sites on the distribution of fishing effort were investigated for a broad selection of French and English demersal fleets operating in the Eastern English Channel. The most prominent result was that most fleets fishing near to aggregate extraction sites were not deterred by extraction activities. The fishing effort of dredgers and potters could be greater adjacent to marine aggregates sites than elsewhere, and also positively correlated to extraction intensity with a lag of 0-9 months. The distribution of fishing effort of French netters remained consistent over the study period. However, it is of note that the fishing effort of netters has increased substantially in the impacted area of the Dieppe site (where it is correlated to extraction intensity with a lag of 6 months), while slightly decreasing in the intermediate and reference areas. The attraction of fishing fleets is likely due to a local temporary concentration of their main target species. However, knowledge of their life-history characteristics and habitat preferences suggests that some of these species could be particularly vulnerable to aggregate extractions in the longer term.
\end{abstract}




\section{Graphical abstract}

Fishing effort of (left panel) French otter-trawlers and of (right panel) English potters operating outside (area "0" in green), around (area "1" in blue) and inside (area "2" in red) English aggregate extraction sites (left panel) UK04 and (right panel) UK05.
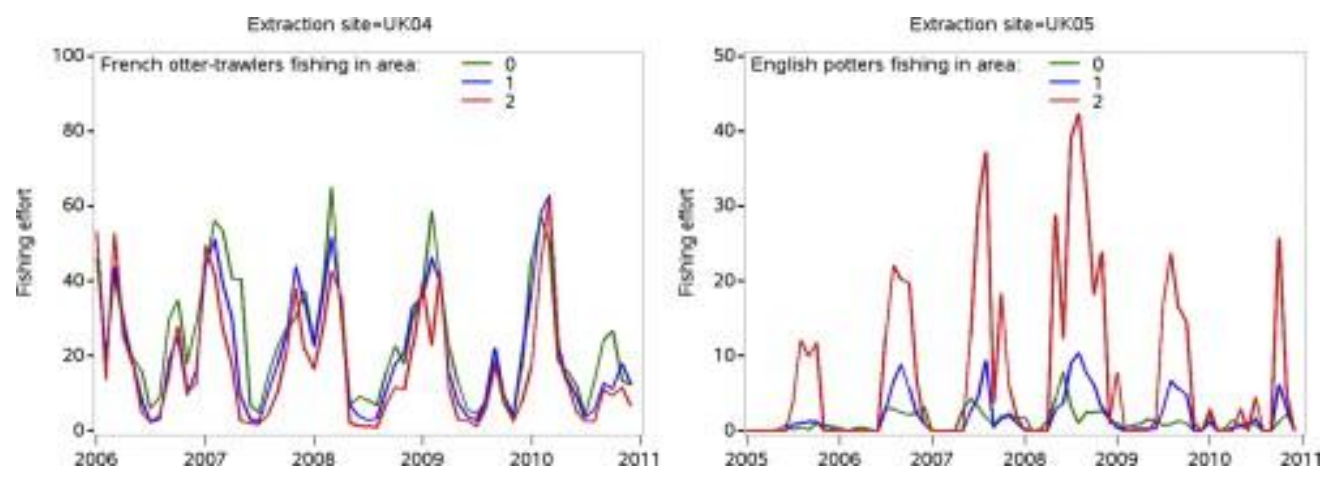

\section{Highlights}

We investigated the effects of aggregate extraction on Eastern Channel fisheries. Most fishing fleets are not deterred by aggregate extractions in the short term. The fishing effort of potters and English dredgers were greater in impacted areas. Fleets could be attracted by a local and temporary concentration of target species. Commercial fleets could be impacted in the longer term by aggregate extractions.

Keywords : spatial management ; spatial planning ; demersal fisheries ; aggregate extraction ; Eastern English Channel 


\section{Introduction}

Human use of maritime domains is increasing and diversifying. The pressures are multiple and interacting, including impacts from the exploitation of living and mineral resources, maritime transport, renewable and non-renewable energy production, in a context of changing environmental conditions. Managing ecosystems is primarily managing people and their activities (Leslie and McLeod, 2007), so a key issue for marine management frameworks is to anticipate some of the patterns underlying human behaviour, their interactions, and the pressures they may exert on the marine ecosystems they exploit.

Until recently, marine resources in most countries worldwide were managed on a mono-sectorial basis. However, because of diverse maritime uses and stressors and their spatial distributions, it is evident that the increasing competition for marine space and the cumulative impact of human activities on marine ecosystems requires a more collaborative, integrated approach to management across the different sectors of activity. This has led many countries worldwide to develop marine management policies aiming at managing human activities by adopting new philosophies such as marine spatial planning (MSP), Integrated Coastal Zone Management (ICZM) and ecosystem-based management (EBM). The European Union (EU) is committed towards ecosystem-based management, and as such, the European Commission (EC) has implemented the Marine Strategy Framework Directive (MSFD - EC, 2007; EC, 2008). The MSFD includes a cross-sectorial framework for community action to achieve good environmental status (GES) of the marine environment by 2020 in the context of sustainable development (EC, 2008), with ICZM and MSP providing a spatially-explicit management instrument to both enforce ecosystem conservation and alleviate competition for space and resources between sectors of activity.

Marine scientists from various backgrounds have increasingly been requested to provide integrated advice (i.e. integrating several elements of the ecosystem and several types of human activities) to inform the MSFD, ICZM and MSP. Providing integrated ecosystem-based advice requires overcoming several research challenges. One of the important challenges for research scientists is to understand the spatial interactions between human activities from different sectors, and to anticipate how human activities could be redirected given various scenarios of spatial management, including any „knock on" effects to the ecosystem. Of particular importance is the issue of how fishers would react (e.g. through a redistribution of fishing effort or by changing métier), if access to traditional fishing grounds was restricted by either, management (e.g. Marine Protected Area MPA), or by spatial competition following the introduction or installation of new sectors of activity.

This study focuses on the Eastern English Channel (henceforth called EEC). The EEC is a productive ecosystem that forms important fishing grounds for a range of commercial species, including herring (Clupea harengus), cod (Gadus morhua), sole (Solea solea), scallops (Pecten maximus) and cephalopods and also encompasses some of their spawning and nursery areas and migratory routes. The EEC has also supported for a long time a wide range of sectors of activity. It is considered one of the most intensively used sea areas in the world, including fishing, maritime transport, aggregate extraction, offshore windfarms, aquaculture and tourism (Carpentier et al., 2009).

Of these human activities, fishing and aggregate extractions are probably the most notable in terms of their direct effects on ecosystem structure and functioning (Pauly et al. 1998, Stelzenmüller et al., 2010; de Jong et al., 2014). Marine aggregates have been exploited along the UK coast of the EEC for several decades, and more recently along the French coast (Desprez, 2000; Boyd and Rees, 2003; ICES, 2013). In 2011, UK and French aggregate extraction companies extracted 17 million tonnes and 10 million cubic metres of marine sand and aggregates, respectively, half of which originated from EEC sites (ICES, 2013). This activity has now spread further offshore, to areas also visited by fishermen, where new extraction licenses have most recently been granted. Therefore, while it is essential to get better insights into how developing aggregate extraction activities could 
affect the EEC ecosystem directly, it is equally important to understand some of their more indirect ecosystem effects, such as those induced by their interferences with fishing activities and the resulting redistribution of fishing effort that may then arise.

Here the purpose of the study was to investigate how fishers and aggregate extractions interact spatially with one another in the EEC, by analyzing time series of different spatially-explicit metrics of fishing activities and aggregate extractions, and using English and French data from both sectors.

\section{Material and methods}

\subsection{Material}

Fisheries information was provided in the same format by IFREMER, the Institut Français pour la Recherche et I'Exploitation de la Mer (French fishing fleets) and CEFAS, the Centre for Environment, Fisheries and Aquaculture Science (English fishing fleets), for the periods 2006-2010 and 2005-2010, respectively. Fishing effort was made available from satellite-based data as hours fished, with a $3^{\prime \prime} \times 3^{\prime \prime}$ spatial resolution. Only those vessels larger than $15 \mathrm{~m}$ were included, because smaller vessels were not equipped with a Vessel Monitoring System (VMS) until 2012 (EC, 2009). Landings were obtained from fishers" EU mandatory logbooks for each fishing trip at the spatial resolution of an ICES (International Council for the Exploration of the Sea) rectangle [1 $\left.1^{\circ} \times 30^{\prime \prime}\right]$. The fishing fleets were distinguished based on the gear used per trip. The most important French fleets, in terms of landings, were otter-trawlers (mainly rigged with an $80 \mathrm{~mm}$ mesh size), netters (mainly using $90 \mathrm{~mm}$ trammel nets), scallop dredgers and potters, while the most important English fleets were scallop dredgers, beam-trawlers (rigged with an $80 \mathrm{~mm}$ mesh size) and potters. Figures 1a and $1 \mathrm{~b}$ show the spatial fishing distribution of all French and UK vessels $>15 \mathrm{~m}$ in the EEC.

Aggregate extraction in the EEC is limited to those areas where deposits of sufficient thickness (sandy gravels and gravelly sands) can be found near the seabed and where water depth does not exceed $50 \mathrm{~m}$ (Vanstaen et al. 2010, Desprez et al. 2014). Extraction intensity for all French and English aggregation extraction sites was collated from the different EEC aggregate extraction companies over the same period covered by fisheries data. The format of these data differed between French and English aggregate extraction companies. For the French aggregate extraction sites, the extraction intensity was made available as number of days dredged per month, and the volume of sand and gravel extracted was also made available. For the English aggregate extraction sites, the extraction intensity was provided as number of hours dredged per month. Extraction intensities were binned into $3^{\prime \prime} \times 3^{\prime \prime}$ squares (Figure 1c). Five aggregate extraction sites were defined in the English Exclusive Economic Zone: UK01 (West of Isle of Wight), UK02 (South-East of Isle of Wight), UK03 (East of Isle of Wight), UK04 (Central EEC) and UK05 (South-East England), and these were treated as independent units for later analyses. Three French aggregate extraction sites were identified and treated independently in this study: FR01 (Baie de Seine), FR02 (Le Havre) and FR03 (Dieppe). The intensity of aggregate extraction varied without a trend in four sites (UK01, UK05, FR02 and FR03) and increased in two sites (UK04 and FR01) (Figures 2-3). Experiments conducted in the sites of Baie de Seine (FR01) and Dieppe (FR03) showed that, in the extraction area, a substantial fraction of the original sandy-gravelly sediment is replaced by pebbles one year after extraction (Desprez et al. 2014). Desprez et al. (2014) also showed that fine sands were deposited in the close neighbourhood of the extraction area $(<2 \mathrm{~km})$.

The average fishing effort by fleet in the different aggregate extraction sites is shown in Table 1 . We restricted the scope of later analysis to the main fishing fleets operating in the different aggregate extraction sites (i.e., those fleets the fishing effort of which was, on average, higher than 0.5 hours per year, per month, and per $3^{\prime \prime} \times 3^{\prime \prime}$ square). There was substantial fishing activity by English scallop dredgers, potters and French otter-trawlers at site UK01 (Figure 2a,b). English scallop dredgers, French otter-trawlers and French scallop dredgers were the main fleets operating in UK04 (Figure 
2c,d). In aggregate extraction site UK05, English beam-trawlers, English potters and French ottertrawlers were the best represented (Figure 2e,f). None of the English and French fleets under investigation had substantial fishing activity in sites UK02 and UK03 (not shown here, see Table 1). French otter-trawlers and French scallop dredgers were the main fleets operating around FR01 (Figure 3a), whilst only French otter-trawlers had a substantial amount of fishing activity around FR03 (Figure 3d). All French fleets (otter-trawlers, scallop dredgers, potters, netters) had substantial fishing activity around FR03 (Figures 3b,c). The English fleets hardly operated in sites FR01, FR02 and FR03 (not shown here).

English beam-trawlers primarily landed sole and plaice, and also a quantity of cephalopods (Loligo spp. and Sepia officinalis) (Table 2). English and French scallop dredgers landed almost exclusively scallops (Pecten maximus). French otter-trawlers operate in a true mixed fishery, mainly landing in different quantities cephalopods, whiting (Merlangius merlangus), red mullet (Mullus surmuletus) and bass (Dicentrarchus labrax). Landing information from English and French potters, although more limited than for other fleets, indicated a clear targeting of whelk (Buccinum undatum) and substantial catches of cephalopods and crustaceans (edible crab - Cancer pagurus and European lobster - Homarus gammarus). Finally, French netters primarily landed sole, with a bycatch of cod (Gadus morhua).

\subsection{Methods}

An investigation was conducted to observe whether and to what extent fishing effort was modified in the areas impacted by aggregate extraction. Aggregate extraction could affect fishing activities as a result of extraction intensity (hypothesis 1), but also through the proximity of the extraction site to the actual fishing grounds (hypothesis 2).

To test the first hypothesis, cross-correlation was calculated between time series of fishing effort and aggregate extraction intensity, which were derived for each aggregate extraction site and for each fishing fleet by averaging values across all spatial units directly impacted by an aggregate extraction site. The interpretation of cross-correlation functions may be blurred by the structure of the explanatory (aggregate extraction intensity) time series and also by any common patterns (e.g., annual trends, seasonality, auto-correlation) both explanatory and response (fishing effort) series may have in common. We overcame that issue by "pre-whitening" both time series, which consisted of, (i) parameterizing an ARIMA model (Box and Jenkins, 1976) to the aggregate extraction time series and then of, (ii) applying the ARIMA model filter estimated in (i) to the fishing effort time series. We could then calculate the cross-correlation between the residuals derived from (i) and the filtered fishing effort values derived from (ii). The cross-correlation was calculated with different time lags to differentiate between instantaneous and delayed effects. Both pre-whitening and crosscorrelation calculations were performed using the PROC ARIMA procedure from the SAS/ETS package (SAS, 2010).

To examine whether and how the distance to aggregate extraction sites had any effect on the spatial allocation of fishing effort, a comparison of fishing effort of the different fleets between three sets of spatial units was conducted. The first set, hereby referred to as the impacted area, included all spatial units where sands and aggregates were extracted, and was allotted a proximity index with a value of 2 . The impacted area cumulated the effects of the extraction itself and of resulting sand deposits. The second set, hereby referred to as the intermediate area, included all spatial units bordering the impacted area (proximity index value $=1$ ). The intermediate area was assumed to be only impacted by the deposition of fine sands following extraction. The distance between the centre of an intermediate spatial unit and the centre of its parent impacted spatial unit ranges between $3^{\text {" }}$ (when the cells share a common edge) and $3 \sqrt{2} \sim 4.2^{\prime \prime}$ (when the cells share a common corner). The final set, hereby referred to as the reference area, included all spatial units bordering the intermediate area (proximity index value $=0$ ). The distance between the centre of each reference spatial unit and the centre of its parent impacted spatial unit ranges between 6 " and $6 \sqrt{2} \sim 8.4$ ". The 
reference area was assumed to be little impacted by aggregate extractions, based on some empirical evidence that fine-sand deposits were limited beyond $2 \mathrm{~km}$ off aggregate extraction sites (Desprez et al. 2014). The larger the proximity index, the closer to the aggregate extraction site. The effect of the proximity to extraction sites on fishing effort was tested using a time series crosssection regression analysis, where each section consisted of the spatial units included in the impacted, intermediate and reference areas, and were the explanatory variable was the proximity index with its three possible values (0: reference area; 1 : intermediate area, 2: impacted area). The analysis was carried out using the SAS procedure PROC TSCREG (SAS, 2010).

\section{Results}

The results of the cross-correlation analyses are shown in Table 3. Pre-whitening was necessary to de-trend and/or de-seasonalize most of the English aggregate extraction intensity time series. The French otter-trawlers fishing effort was positively cross-correlated to aggregate extraction intensity with a time lag of 0-3 months, and then negatively correlated with a time lag of 4-8 months, on sites FR02 (Figure 3b) and FR03 (Figure 3c). A reverse pattern was found between the fishing effort of French otter-trawlers and aggregate extraction intensity on site UK04, with a negative crosscorrelation at lag 2 and a positive cross-correlation at lag 5 (Figure 2d). The fishing effort of French otter-trawlers was negatively cross-correlated to aggregate extraction intensity with a time lag of 6 months on site UK01 (Figure 2b). The fishing effort of English and French potters was positively cross-correlated with aggregate extraction intensity at lags 0 (instantaneously) in site UK01 (Figure 2a) and 2-3 months in site FR03 (Figure 3d), respectively. A positive cross-correlation between the fishing effort of French dredgers and aggregate extraction intensity was found at lag 6 in site UK04 (Figure 2d), and at lag 9 in site FR03 (Figure 3c). The fishing effort of French netters was positively cross-correlated with aggregate extraction intensity at lag 6 in site FR03 (Figure 3d). The crosscorrelation between the other fishing effort and aggregate extraction intensity time series was not significant ( $p>0.05)$, or could not be calculated when the time series was too short (FR01).

The results of the time series cross-section regression analysis indicated that the fishing effort of English and French potters was larger in the vicinity of all aggregate extraction sites where they were observed (Figures 4b, 4h, 5f). The fishing effort of English scallop dredgers targeting scallops also increased with the proximity to aggregate extraction sites UK01 (Figure 4a) and UK04 (Figure $4 d)$. Only the fishing effort of French otter-trawlers decreased in the vicinity of aggregate extraction site UK05 (Figure 4i). The distribution of fishing effort was not related to the distance to aggregate extraction sites for the other fleets.

Finally the relative annual shifts in fishing effort (i.e. ratio between current effort and the effort at the start of the time series) were compared across the impacted, intermediate and reference areas. The difference across the three areas was generally minimal for most fleets operating around English and French aggregate extraction sites (Figures 6a-b, 6e-i, 7a-b, 7d-e). On English aggregate extraction site UK04, the fishing effort of English dredgers in the impacted and intermediate areas increased substantially compared to that in the reference area (Figure 6d). On the French aggregate extraction sites, an increase in fishing effort was evident in the impacted area for French otter-trawlers (Figure 7c), French potters (Figure 7f) and French netters (Figure 7g), while the fishing effort in the intermediate and reference areas remained constant or even decreased. 


\section{Discussion}

\subsection{Effects of aggregate extractions on fleet dynamics}

In this study, the effects of both extraction intensity and the proximity to aggregate extraction sites on the distribution of fishing effort were investigated for a broad selection of French and English demersal fleets. The most striking result was that, for most of the fishing fleets and aggregate extraction sites, neither extraction intensity nor the proximity to the extraction site had a substantial deterring effect on fishing activities. To the contrary, we noted that the fishing effort of dredgers and potters could be greater in the vicinity of marine aggregates sites than elsewhere and also positively correlated to extraction intensity with a lag of 0 to 9 months. The fishing effort distribution of French netters was consistent over the whole time period under investigation. However, it is important to note that in FR03, the fishing effort of netters has overall increased in the impacted area since 2006 (where it is correlated to extraction intensity with a lag of 6 months), whilst slightly decreasing in the intermediate and reference areas over the same period. The results obtained for French ottertrawlers were clearly mixed and site-dependent.

The general lack of a negative impact of aggregate extractions on fishing activities bear out the outcomes of preliminary impact studies conducted by Vanstaen et al. (2010) on English aggregate sites in the EEC, over various time periods. Vanstaen et al. (2010) concluded there was no evidence that marine aggregates exploitation had significantly altered the spatial fishing distribution of fleets operating various mobile gears. Vanstaen et al. (2010) even indicated some increase of fishing activity for scallop dredgers targeting scallops in the vicinity of marine aggregates sites exploited in the central EEC (referred to as UK04 in this investigation).

\subsection{Biological and ecological drivers of fleets' responses to aggregate extractions}

To understand why marine aggregates extractions did not have the negative impact one would have anticipated on fishing activities, it is necessary to consider the biological and ecological effects of aggregate extractions on marine organisms, and the habitat utilization of target species. It has been shown that aggregate extractions can result in an immediate reduction in the total biomass and species number of benthic invertebrates due to sediment disturbance (Desprez et al., 2000; Boyd and Rees, 2003; Barry et al., 2010; Desprez et al., 2010). The recolonization may last several years, possibly with a durable change in the composition of the benthic community when the nature of the sediment composition has been thoroughly modified (Cooper et al., 2013). However, concomitantly to the immediate removal of benthos, the water column is enriched by the organic matter derived from the dredger outwash (Newell, 1999). In the vicinity of some EEC aggregate extraction sites, the increased deposition of organic detritus during extraction is known to attract suspension-feeders, omnivorous, and/or scavenging species (e.g., porcelain crab, Pisidia longicornis, and squat lobster, Galathea intermedia) and also fish such as common sole, black seabream, and cod (Desprez et al., 2014).

These ecological considerations could in particular explain why French and English potters, targeting scavenging species such as whelk, European lobster and edible crab (Carpentier et al., 2009) have concentrated in the vicinity of all aggregate extraction sites around which these fleets normally operate. Scallop is a suspension feeder (Carpentier et al., 2009), and so might feed on any increased organic matter in the water column. Importantly also, this species has a habitat preference for coarse sand and gravel sediments, which are also those exploited by aggregate extraction companies (Dare et al., 1993). Such factors could explain why English scallop dredgers (which target this species almost exclusively) were relatively more densely distributed over some aggregate extraction sites (e.g., UK01 and UK04). A temporary increased abundance of sole in the vicinity of some French extraction sites, which has empirically been observed by Desprez et al. (2014), could explain why the increase in fishing effort of the French netters targeting predominantly this species 
has been substantially larger on the impacted site than in the neighbouring areas. Sole are nonvisual feeders and presumably not able of catching mobile epifauna (Piet et al., 1998). The effects of aggregate extractions could be to temporarily increase the amount of sole preys, either dead invertebrates directly crushed by the dredger, or alive polychaetes and molluscs, which could benefit from the increased fraction of fines in the seabed located in the close neighbourhood of aggregate extraction areas (Desprez et al., 2014). A dynamic change in extraction intensity is in some cases associated with a change in the same direction of fishing effort for these fleets up to 6 months later, which may indicate a persistent modification of the benthic community structure following extraction (Desprez, 2000; Boyd et al., 2003; Cooper et al., 2007; Foden, 2009). The linkage between aggregate extraction and fishing effort of otter trawlers is more complex to interpret, possibly because this fleet targets a range of species which may respond differently to changes in prey distributions following aggregate extraction.

These results were considered in the light of those obtained from other studies investigating the impact of aggregate extractions on commercial fish and shellfish species. Steltzenmüller et al. (2010) developed a sensitivity index based on several ecological and life-history characteristics: type of spatial distribution, threat status, importance for fisheries, habitat vulnerability, ability to switch diet and affinity to seabed. Of the 11 case study species considered, scallop and lobster reached the highest scoring, indicating a great vulnerability to aggregate extractions. The scoring for edible crabs and sole was lower, and whelk was not considered. Drabble (2012) suggested that aggregate extractions in site UK04 may have a deterring effect on the recruitment and also the spawning biomass of sole and plaice, which could be explained by draghead entrainment. Such species response could not be confirmed by our study since the fishing effort of the main fleets targeting these two species (English beam trawlers and French netters) was relatively low within and in the neighbourhood of aggregate extraction site UK04. However, studies conducted in other eco-regions than the EEC also evidenced adverse effects of large-scale aggregate extractions on the total abundance of commercial fish (Hwang et al., 2013; de Jong et al., 2014).

To conclude, while our results generally suggest that a concentration of species such as sole, lobster, edible crab, whelk, scallop and the fleets which target them is locally and temporarily possible in the vicinity of relatively small-size aggregate extraction sites, knowledge on their lifehistory characteristics and habitat preferences suggests that some of these species could be particularly vulnerable to aggregate extractions in the longer term.

\subsection{Methodological and data considerations}

In this study, we have analysed the effect of aggregate extractions on the spatial distribution of fishing effort using two complementary approaches: cross-correlation and time series cross-section regression analyses. An alternative approach, more traditionally used in impact assessments, could have been to conduct a Before-After Control-Impact (BACl) analysis (Smith, 2002; Torres-Irineo et al., 2011). Such a BACl approach would be useful to estimate the magnitude of the effects of aggregate extractions on fishing effort. However, unlike the analyses being conducted in this study, the $\mathrm{BACl}$ approach could not inform on the more detailed impact, including lag effects, of both aggregate extraction intensity and distance to extraction sites, on the spatial and temporal distribution of fishing effort. Also the $\mathrm{BACl}$ approach would require data prior to the extraction period which, in our case, could only be available for two sites: FR01 and UK04.

It is important to note that the main material used in this study consisted of fishing vessels of length above $15 \mathrm{~m}$. Therefore, it remains to be investigated how the small-scale vessels (of length lesser that $15 \mathrm{~m}$ ) would interact with aggregate extraction sites. This is particularly true for netters and potters, the majority of which do not exceed $12 \mathrm{~m}$. Another question which should be addressed in future investigations is whether the relative changes in fishing effort observed are really associated with corresponding changes in catch rates. For instance, one may wonder whether the increase in fishing effort of English and French potters in the vicinity of aggregate extraction sites is indeed 
driven by the expectation of large whelks or crustaceans catch rates. Such an approach could not be conducted in this study, since catch data were only available at the coarse spatial scale of the ICES rectangle. However, the current development of electronic logbooks may offer an opportunity to collect high resolution catch data that could be used in future studies to further explore the impact of aggregate extractions on the abundance of commercial species and on the fishing fleets which target them.

\section{Acknowledgements}

This study was funded by the European Community"s Seventh Framework Programme (FP7/20072013) under Grant Agreement No. 266445 for the project Vectors of Change in Oceans and Seas Marine Life, Impact on Economic Sectors (VECTORS). We are also indebted to the thoughtful comments of three anonymous referees who helped to improve the manuscript.

\section{References}

Barry, J., Boyd, S., Fryer, R., 2010. Modelling the effects of marine aggregate extraction on benthic assemblages. J. Mar. Biol. Assoc. UK 90, 105-114.

Box, G.E.P., Jenkins, G.M., 1976. Time Series Analysis: Forecasting and Control, San Francisco: Holden-Day.

Boyd, S.E., Rees, H.L., 2003. An examination of the spatial scale of impact on the marine benthos arising from marine aggregate extraction in the central English Channel. Estuar. Coast. Shelf Sci. 57, 1-16.

Boyd, S.E., Limpenny, D.S., Rees, H.L., Cooper, K.M., Campbell, S., 2003. Preliminary observations of the effects of dredging intensity on the re-colonisation of dredged sediments off the southeast coast of England (Area 222). Estuar. Coast. Shelf Sci. 57, 116.

Carpentier, A., Martin, C.S., Vaz, S. (Eds), 2009. Channel Habitat Atlas for marine Resource Management, final report / Atlas des habitats des resources marines de la Manche orientale, rapport final (CHARM phase II). INTERREG 3a Programme, IFREMER, Boulogne s/mer, France, 626 pp. \& CD-rom.

Cooper, K.M., Boyd, S.E., Eggleton, J.D., Limpenny, D.S., Rees, H.L., Vanstaen, K., 2007. Recovery of the seabed following marine aggregate dredging on the Hastings Shingle Bank, SE England. Estuar., Coast. Shelf Sci. 75, 547-558.

Cooper, K., Burdon, D., Atkins, J.P., Weiss, L., Somerfield, P., Elliott, M., Turner, K., Ware, S., Vivian, C., 2013. Can the benefits of physical seabed restoration justify the costs? An assessment of a disused aggregate extraction site off the Thames Estuary, UK. Mar. Pollut. Bull. 75, 33-45.

Dare, P.J., Darby, C.D., Durance, J.A., Palmer, D.W., 1993. The distribution of scallops, Pecten maximus, in the English Channel and Celtic Sea in relation to hydrographic and substrate features affecting larval dispersal and settlement. In Proceedings of the 9th International Pectinid Workshop, Nanaimo, BC, Canada, Vol. 1, pp. 20-27.

de Jong, M.F., Baptist, M.J., van Hal, R., de Boois, I.J., Lindeboom, H.J., and Hoekstra, P., 2014. Impact on demersal fish of a large-scale and deep sand extraction site with ecosystembased landscaped sandbars. Estuar., Coast. Shelf Sci. 146, 83-94.

Desprez, M., 2000. Physical and biological impact of marine aggregate extraction along the French coast of the eastern English Channel: short and long-term post-dredging restoration. ICES J. Mar. Sci. 57, 1428-1438. 
Desprez, M., Pearce, B., Le Bot, S., 2010. The biological impact of overflowing sands around a marine aggregate extraction site: Dieppe (eastern English Channel). ICES J. Mar. Sci. 67, 270-277.

Desprez, M., Le Bot, S., Duclos, P.-A., de Roton, G., Villanueva, M., Ernande, B., Lafite, R., 2014. Monitoring the impacts of marine aggregate extraction. Knowledge Synthesis 2012 (GIS SIEGMA). Presses universitaires de Rouen et du Havre, 43 pp.

Drabble, R., 2012. Monitoring of East Channel dredge areas benthic fish population and its implications. Mar. Pollut. Bull. 64, 363-372.

EC, 2007. Communication de la Commission au Parlement européen, au Conseil, au Comité économique et social européen et au Comité des régions. Une politique maritime intégrée pour l'Union européenne. Brussels, EC, COM(2007) 575 final, 10 October 2007.

EC, 2008. Directive 2008/56/EC of the European Parliament and of the Council of 17 June 2008 establishing a framework for community action in the field of marine environmental policy (Marine Strategy Framework Directive).

EC, 2009. EC Regulation No. 1224/2009 of 20 November 2009 establishing a Community control system for ensuring compliance with the rules of the Common Fisheries Policy, amending Regulations (EC) No. 847/96, (EC) No 2371/2002, (EC) No. 811/2004, (EC) No. 768/2005, (EC) No. 2115/2005, (EC) No. 2166/2005, (EC) No. 388/2006, (EC) No. 509/2007, (EC) No. 676/2007, (EC) No. 1098/2007, (EC) No. 1300/2008, (EC) No. $1342 / 2008$ and repealing Regulations (EEC) No. 2847/93, (EC) No. 1627/94 and (EC) No. 1966/2006. Official Journal of the European Union 2009, L343: 1-50.

Foden, J., Rogers, S.I., Jones, A.P., 2009. Recovery rates of UK seabed habitats after cessation of aggregate extraction. Mar. Ecol. Prog. Ser. 390, 15-26.

Hwang, S.W., Lee, H.G., Choi, K.H., Kim, C.K., Lee, T.W., 2013. Impact of sand extraction on fish assemblages in Gyeonggi Bay, Korea. J. Coast. Res.

ICES, 2013. Report of the Working Group on the effects of extraction of marine sediments on the marine ecosystems (WGEXT). ICES CM2013 / SSGHIE:14, 54 pp.

Leslie, H.M., McLeod, K.L., 2007. Confronting the challenges of implementing marine ecosystembased management. Front. Ecol. Environ. 5, 540-548.

Newell, R.C., Hitchcock, D.R., Seiderer, L.J., 1999. Organic enrichment associated with outwash from marine aggregates dredging: a probable explanation for surface sheens and enhanced benthic production in the vicinity of dredging operations. Mar. Pollut. Bull. 38, 808-818.

Pauly, D., Christensen, V., Dalsgaard, J., Froese, R., Torres, F., 1998. Fishing down marine food webs. Science $279,860-863$.

SAS, 2010. SAS Institute Inc., Cary, NC, USA. SAS/ETS package, version 9.3.

Smith, E.P., 2002. BACl design. In: El-Shaarawi, A.H., Piegorsch, W.W. (Eds.), Vol. I, Encyclopedia of Environmetrics. John Wiley \& Sons, Ltd, Chichester, pp. 141-148.

Stelzenmüller, V., Ellis, J.R., Rogers, S.I., 2010. Towards a spatially explicit risk assessment for marine management. Assessing the vulnerability of fish to aggregate extraction. Biol. Conserv. 143, 230-238.

Torres-Irineo, E., Gaertner, D., Delgado de Molina, A., Ariz, J., 2011. Effects of time-area closure on tropical tuna purse-seine fleet dynamics through some fishery indicators. Aquat. Living Resour. 24, 337-350.

Vanstaen, K., Clark, R., Ware, S., Eggleton, J., James, J.C.W., Cotteril, C., Rance, J., Manco, F., Woolmer, A., 2010. Assessment of the distribution and intensity of fishing activities in the vicinity of aggregate extraction sites. MALSF-MEPF Project 08/P73. Cefas, Lowestoft, $116 \mathrm{pp}$. 
Table 1. Hours fished averaged over years (2006-2010 and 2005-2010 for the French and English fleets, respectively), month, and $3^{\prime \prime} \times 3^{\prime \prime}$ square (with standard error in bracket) of English beamtrawlers (ENG_TBB), English dredgers (ENG_DRD), English potters (ENG_POT), French ottertrawlers (FRA_OTB), French dredgers (FRA_DRD), French potters (FRA_POT) and French netters (FRA_NET), in English aggregate extraction sites (UK01, UK02, UK03, UK04, UK05) and French aggregate extraction sites (FR01, FR02, FR03).

\begin{tabular}{llllllll}
\hline & ENG_TBB & ENG_DRD & ENG_POT & FRA_OTB & FRA_DRD & FRA_POT & FRA_NET \\
\hline UK01 & $<0.5$ & $7.1(0.7)$ & $2.7(0.3)$ & $3.5(0.2)$ & $<0.5$ & $<0.5$ & $<0.5$ \\
UK02 & $<0.5$ & $<0.5$ & $<0.5$ & $<0.5$ & $<0.5$ & $<0.5$ & $<0.5$ \\
UK03 & $<0.5$ & $<0.5$ & $<0.5$ & $<0.5$ & $<0.5$ & $<0.5$ & $<0.5$ \\
UK04 & $<0.5$ & $7.6(0.7)$ & $<0.5$ & $17.1(0.9)$ & $19.8(1.0)$ & $<0.5$ & $<0.5$ \\
UK05 & $2.0(0.4)$ & $<0.5$ & $7.6(1.3)$ & $3.0(0.5)$ & $<0.5$ & $<0.5$ & $<0.5$ \\
\hline FR01 & $<0.5$ & $<0.5$ & $<0.5$ & $10.9(1.6)$ & $6.9(1.5)$ & $<0.5$ & $<0.5$ \\
FR02 & $<0.5$ & $<0.5$ & $<0.5$ & $5.0(0.7)$ & $<0.5$ & $<0.5$ & $<0.5$ \\
FR03 & $<0.5$ & $<0.5$ & $<0.5$ & $19.4(3.8)$ & $6.1(1.9)$ & $0.6(0.3)$ & $2.1(0.3)$ \\
\hline
\end{tabular}


Table 2. Proportion (calculated in the whole EEC over the period 2007-2010) of sole (Solea solea), plaice (Pleuronectes platessa), cephalopods (Sepia officinalis and Loligo sp.), scallops (Pecten maximus), bass (Dicentrarchus labrax), red mullet (Mullus surmuletus), whiting (Merlangius merlangus), cod (Gadus morhua), large crustaceans (edible crab, Cancer pagurus, European lobster, Homarus gammarus) and whelks (Buccinum undatum) in the total landing value of English beam-trawlers (ENG TBB), English dredgers (ENG DRD), English potters (ENG_POT), French otter-trawlers (FRA_OTB), French dredgers (FRA_DRD), French potters (FRA_POT), and French (FRA_NET).

\begin{tabular}{|c|c|c|c|c|c|c|}
\hline ENG_TBB & ENG_DRD & ENG_POT & FRA_OTB & FRA_DRD & FRA_POT & FRA_NET \\
\hline Sole (33\%) & Scallops & Whelks $(61 \%)$ & Cephalopods & Scallops & Whelks (56\%) & Sole $(74 \%)$ \\
\hline Plaice (26\%) & $(99 \%)$ & Crustaceans & $(34 \%)$ & $(95 \%)$ & Cephalopods & Cod $(6 \%)$ \\
\hline \multirow[t]{4}{*}{ Cephalopods (7\%) } & & $(39 \%)$ & Whiting (11\%) & & $(33 \%)$ & \\
\hline & & & Red mullet (8\%) & & Crustaceans (7\%) & \\
\hline & & & Bass (8\%) & & & \\
\hline & & & Cod $(4 \%)$ & & & \\
\hline
\end{tabular}


Table 3. Tests of, (1) cross-correlation between fishing effort and aggregate extraction intensity time series and, (2) effect of the proximity from extraction sites on fishing effort (as output from time series cross-section regression analysis), for different French/English fleets and extraction sites ("-" means not statistically significant with $p<0.05)$. The time series have been pre-whitened using an $\operatorname{ARIMA}(p, d, q)$ model, where " $p$ " is the order of the autoregressive part of the model, " $d$ " is the order of the differencing and " $q$ " is the order(s) of the moving-average process.

\begin{tabular}{|c|c|c|c|c|c|c|c|}
\hline \multirow[t]{2}{*}{ Extraction site } & \multicolumn{3}{|c|}{ Pre-whitening } & \multirow[t]{2}{*}{ Fleet } & \multirow{2}{*}{$\begin{array}{l}\text { Cross- } \\
\text { correlation } \\
\text { Lags } \\
\text { (correlation) }\end{array}$} & \multicolumn{2}{|c|}{ Proximity to extraction } \\
\hline & $\bar{p}$ & $d$ & $q$ & & & Coefficient & $\mathrm{p}$ \\
\hline \multirow[t]{3}{*}{ UK01 } & 1 & 0 & 0 & English dredgers & ns & 3.11 & $<0.01$ \\
\hline & & & & English potters & $0(+)$ & 1.23 & $<0.01$ \\
\hline & & & & French otter-trawlers & $6(-)$ & -0.95 & 0.24 \\
\hline \multirow[t]{3}{*}{$\overline{U K 04}$} & 1 & 0 & 1,12 & English dredgers & ns & 2.25 & $<0.01$ \\
\hline & & & & French otter-trawlers & $2(-) ; 5(+)$ & -3.64 & 0.11 \\
\hline & & & & French dredgers & $6(+)$ & 2.38 & 0.07 \\
\hline \multirow[t]{3}{*}{ UK05 } & 12 & 0 & 1 & English beam-trawlers & ns & 0.65 & 0.13 \\
\hline & & & & English potters & ns & 2.05 & 0.04 \\
\hline & & & & French otter-trawlers & ns & -11.12 & 0.01 \\
\hline \multirow[t]{2}{*}{$\overline{\text { FR01 }}$} & - & - & - & French otter-trawlers & - & -1.32 & 0.43 \\
\hline & - & - & - & French dredgers & - & -3.35 & 0.14 \\
\hline \multirow[t]{2}{*}{$\overline{\text { FR02 }}$} & 0 & 0 & 0 & French otter-trawlers & $(2,3)(+) ;(7,8)(-$ & 1.73 & 0.36 \\
\hline & & & & & ) & & \\
\hline \multirow[t]{5}{*}{ FR03 } & 0 & 0 & 0 & French otter-trawlers & $(0,2)(+) ;(4,5)(-$ & 2.62 & 0.47 \\
\hline & & & & & ) & & \\
\hline & & & & French dredgers & $9(+)$ & 1.40 & 0.16 \\
\hline & & & & $\overline{\text { French potters }}$ & $(2,3)(+)$ & 0.20 & $<0.01$ \\
\hline & & & & French netters & $6(+)$ & 0.12 & 0.78 \\
\hline
\end{tabular}




\section{Figures caption}

Figure 1. EEC maps showing the spatial distribution $\left(3^{\prime \prime} \times 3^{\prime \prime}\right)$ of, (a) the hours fished by French vessels exceeding $15 \mathrm{~m}$ cumulated over 2007-2012, (b) the hours fished by UK vessels exceeding 15 m over 2007-2011 and, (c) extraction intensity in the vicinity of all French and UK aggregate extraction sites identified by their respective codes: FR01 (Baie de Seine), FR02 (Le Havre), FR03 (Dieppe), UK01-UK05.

Figure 2. Aggregate extraction intensity (average surface exploited per month and per $3^{\prime \prime} \times 3^{\prime \prime}$ square) in English aggregate extraction sites (a, b) UK01, (c, d) UK04, (e, f) UK05; fishing effort (average hours fished per month and per $3^{\prime \prime} \times 3^{\prime \prime}$ square - plain line) of (a) English beam-trawlers \& potters fishing in UK01, (b) French otter-trawlers fishing in UK01, (c) English dredgers fishing in UK04, (d) French otter-trawlers \& dredgers fishing in UK04, (e) English beam-trawlers and potters fishing in UK05 and, (f) French otter-trawlers fishing in UK05.

Figure 3. Aggregate extraction intensity (average surface exploited per month and per $3^{\prime \prime} \times 3^{\prime \prime}$ square) in French aggregate extraction sites (a) FR01, (b) FR02, (c, d) FR03; fishing effort (average hours fished per month and per $3^{\prime \prime} \times 3^{\prime \prime}$ square - plain line) of (a) French otter-trawlers \& dredgers fishing in FR01, (b) French otter-trawlers fishing in FR02, (c) French otter-trawlers \& dredgers fishing in FR03 and, (d) French potters \& netters fishing in FR03.

Figure 4. Fishing effort (average hours fished per month and per $3^{\prime \prime} \times 3^{\prime \prime}$ square) of (a, d) English dredgers, (b, h) English potters, (g) English beam-trawlers, (c, e, i) French otter-trawlers, (f) French dredgers, inside (area 2, thick plain line), around (area 1, thin plain line) and outside (area 0, thin dotted line) English aggregate extraction sites (a, b, c) UK01, (d, e, f) UK04, (g, h, i) UK05.

Figure 5. Fishing effort (average hours fished per month and per $3^{\prime \prime} \times 3^{\prime \prime}$ square) of (a, c, d), French otter-trawlers, (b, e) French dredgers, (f) French potters, (g) French netters, inside (area 2, thick plain line), around (area 1, thin plain line) and outside (area 0 , thin dotted line) French aggregate extraction sites (a, b) FR01, (c) FR02, (d, e, f, g) FR03.

Figure 6. Annual trends in fishing effort (average hours fished per month and per $3^{\prime \prime} \times 3^{\prime \prime}$ square relative to starting year) of (a, d) English dredgers, (b, h) English potters, (g) English beam-trawlers, (c, e, i) French otter-trawlers, (f) French dredgers, inside (area 2, thick plain line), around (area 1, thin plain line) and outside (area 0 , thin dotted line) English aggregate extraction sites $(a, b, c)$ UK01, (d, e, f) UK04, (g, h, i) UK05.

Figure 7. Annual trends in fishing effort (average hours fished per month and per $3^{\prime \prime} \times 3^{\prime \prime}$ square relative to starting year) of (a, c, d), French otter-trawlers, (b, e) French dredgers, (f) French potters, (g) French netters, inside (area 2, thick plain line), around (area 1, thin plain line) and outside (area 0 , thin dotted line) French aggregate extraction sites (a, b) FR01, (c) FR02, (d, e, f, g) FR03. 
Figure 1.

(a)

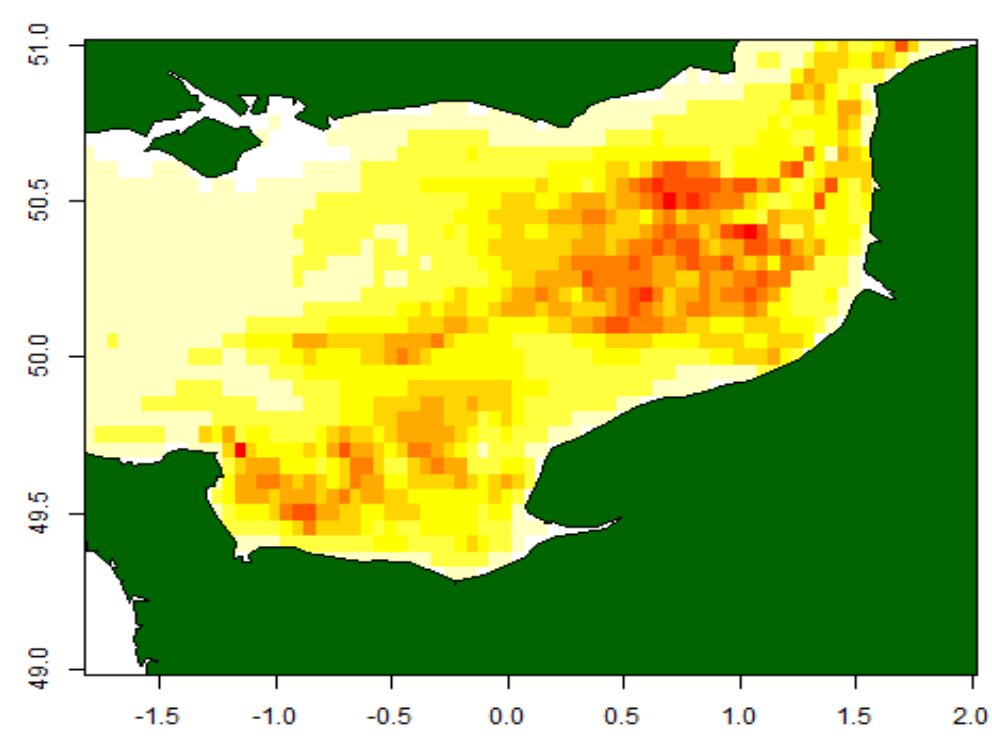

(c)

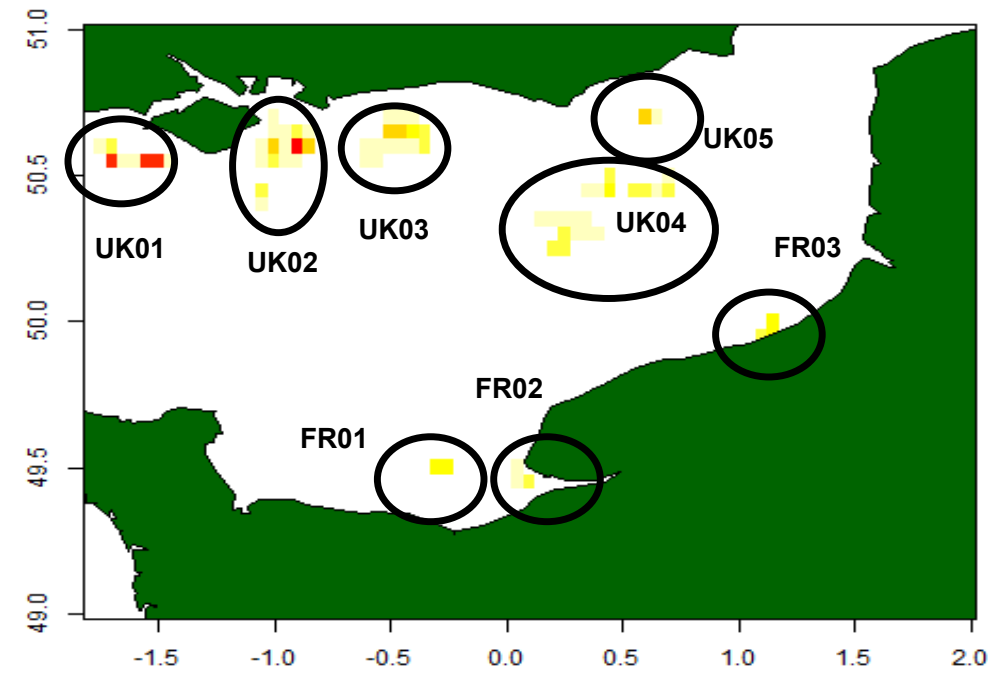

(b)

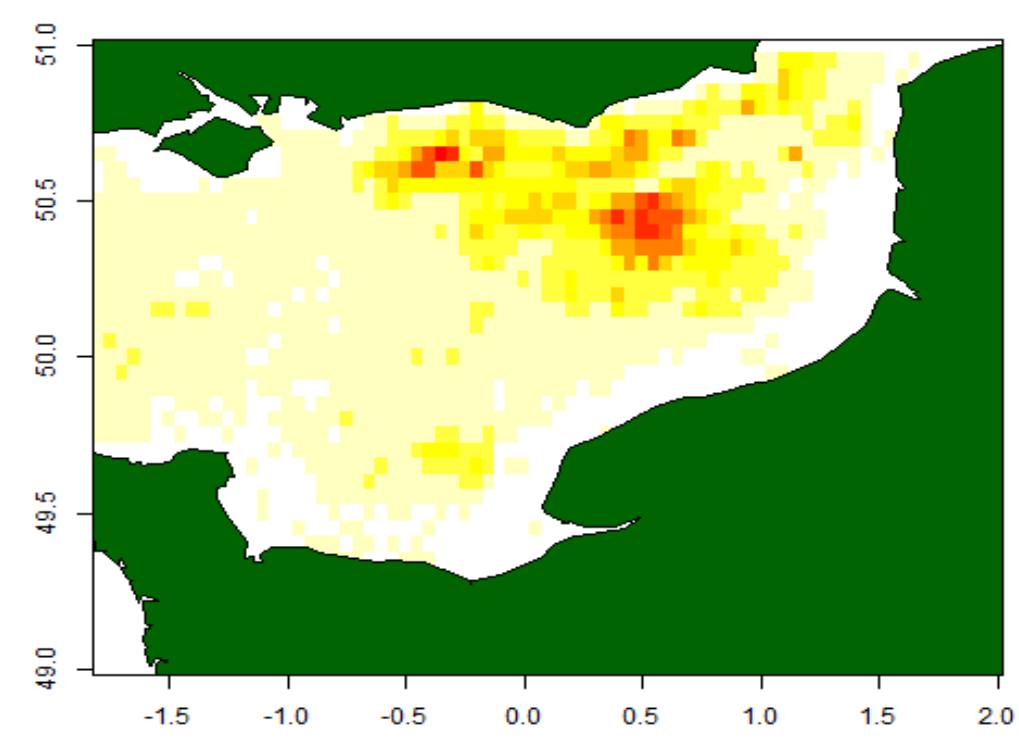


Figure 2.

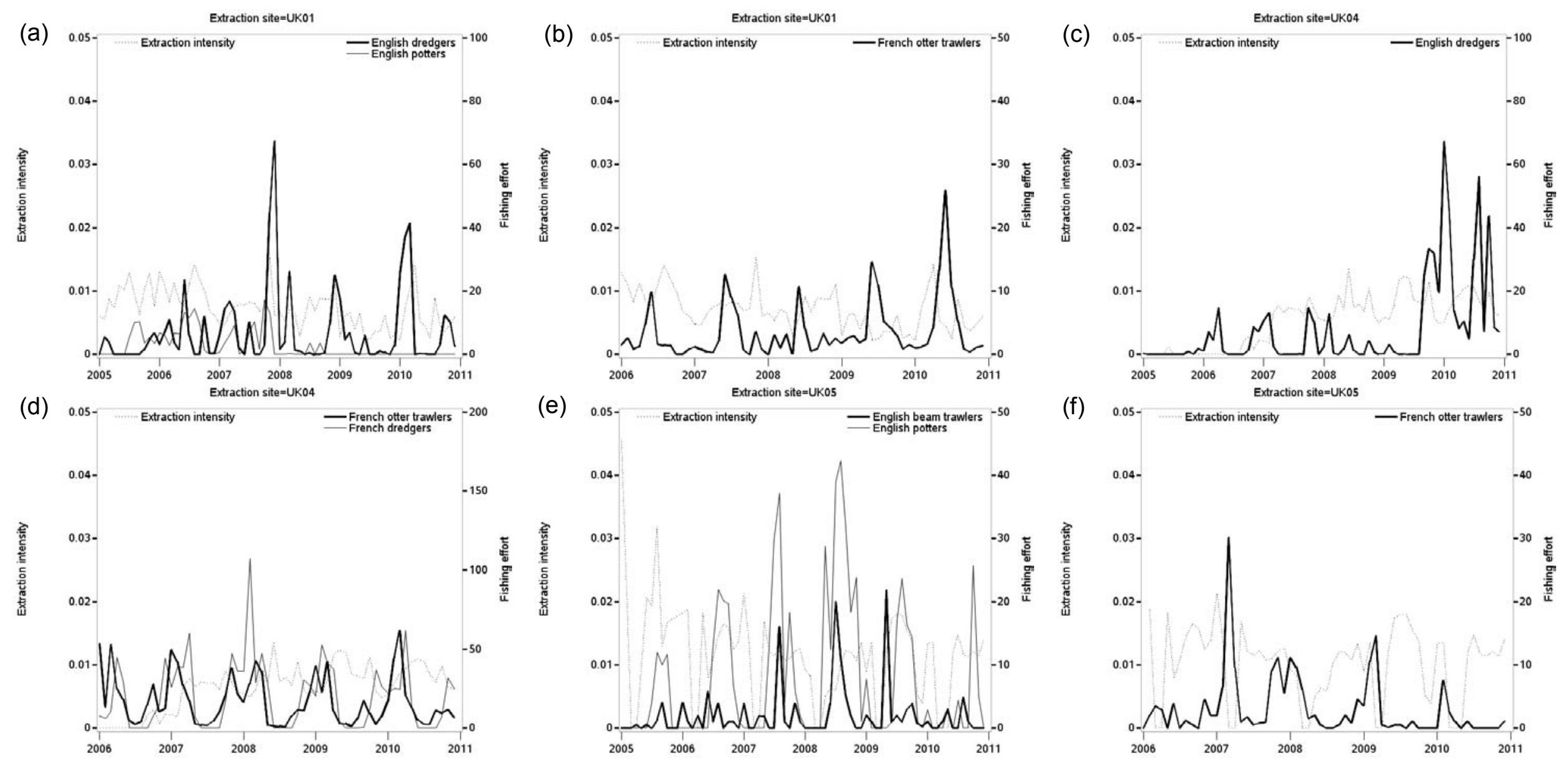


Figure 3.

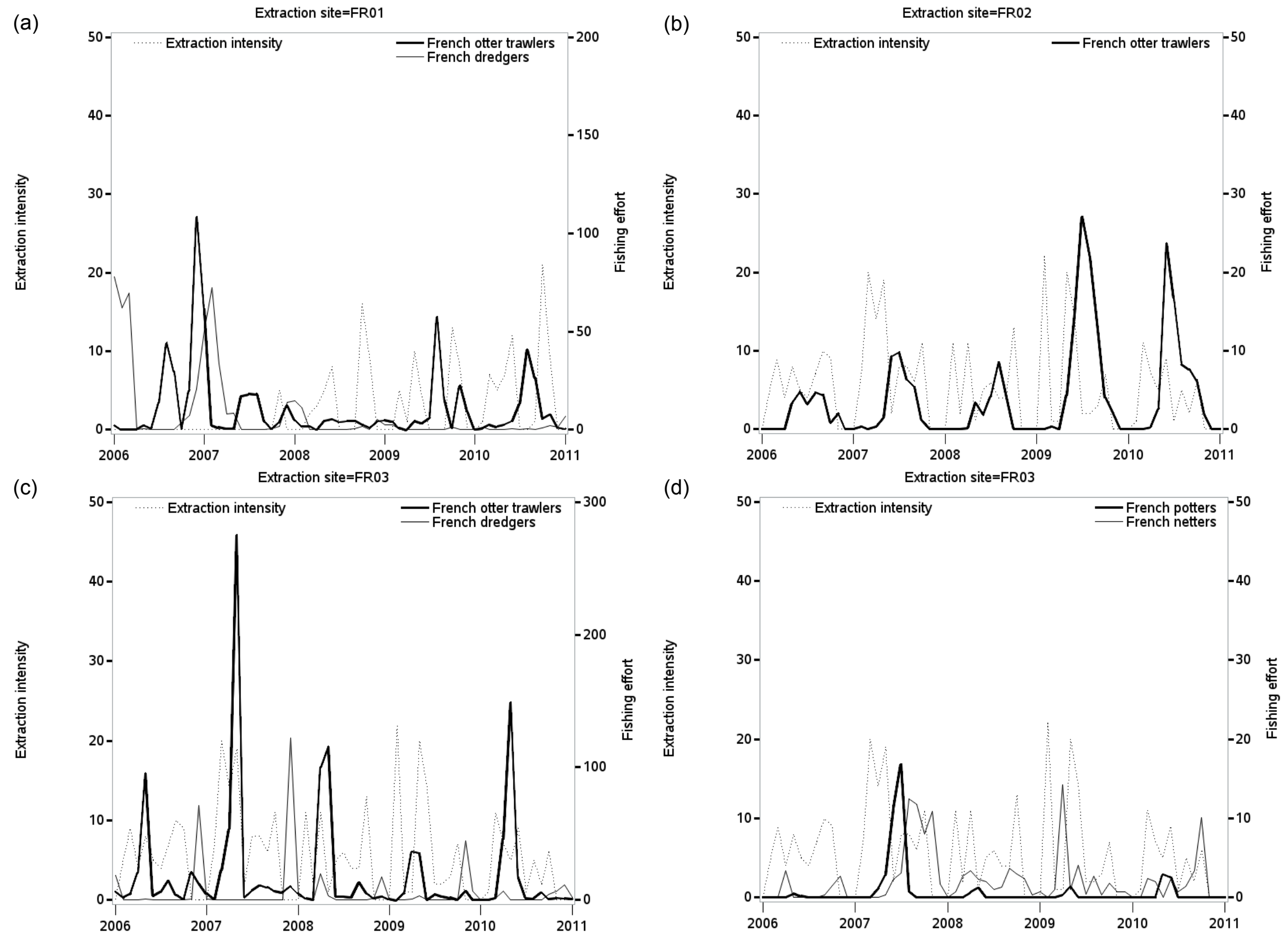


Figure 4.
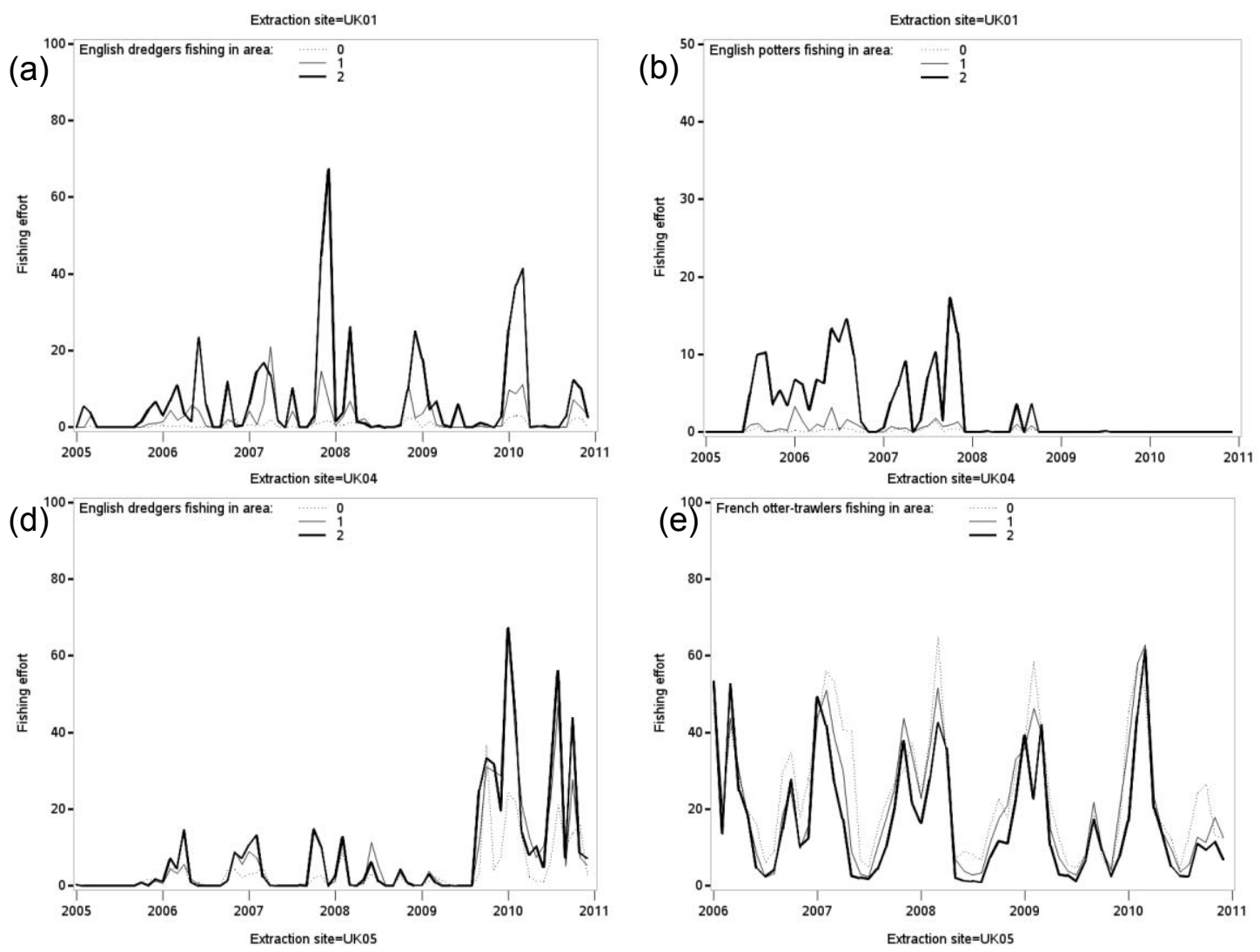

(g)

$\left(e^{100-}\right.$

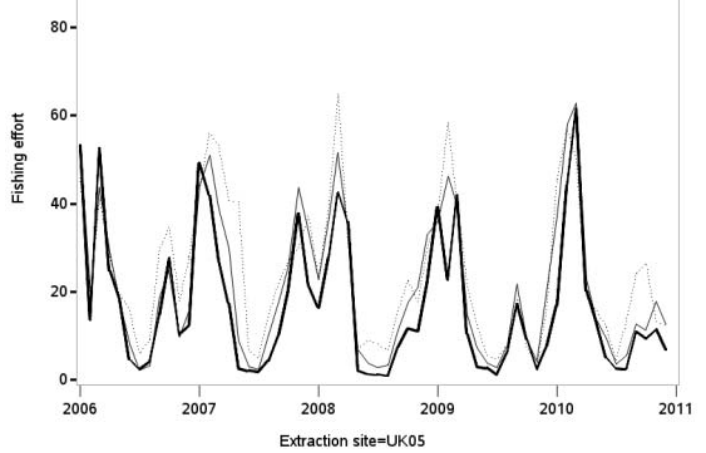

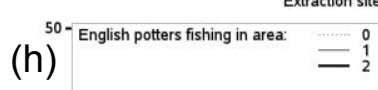
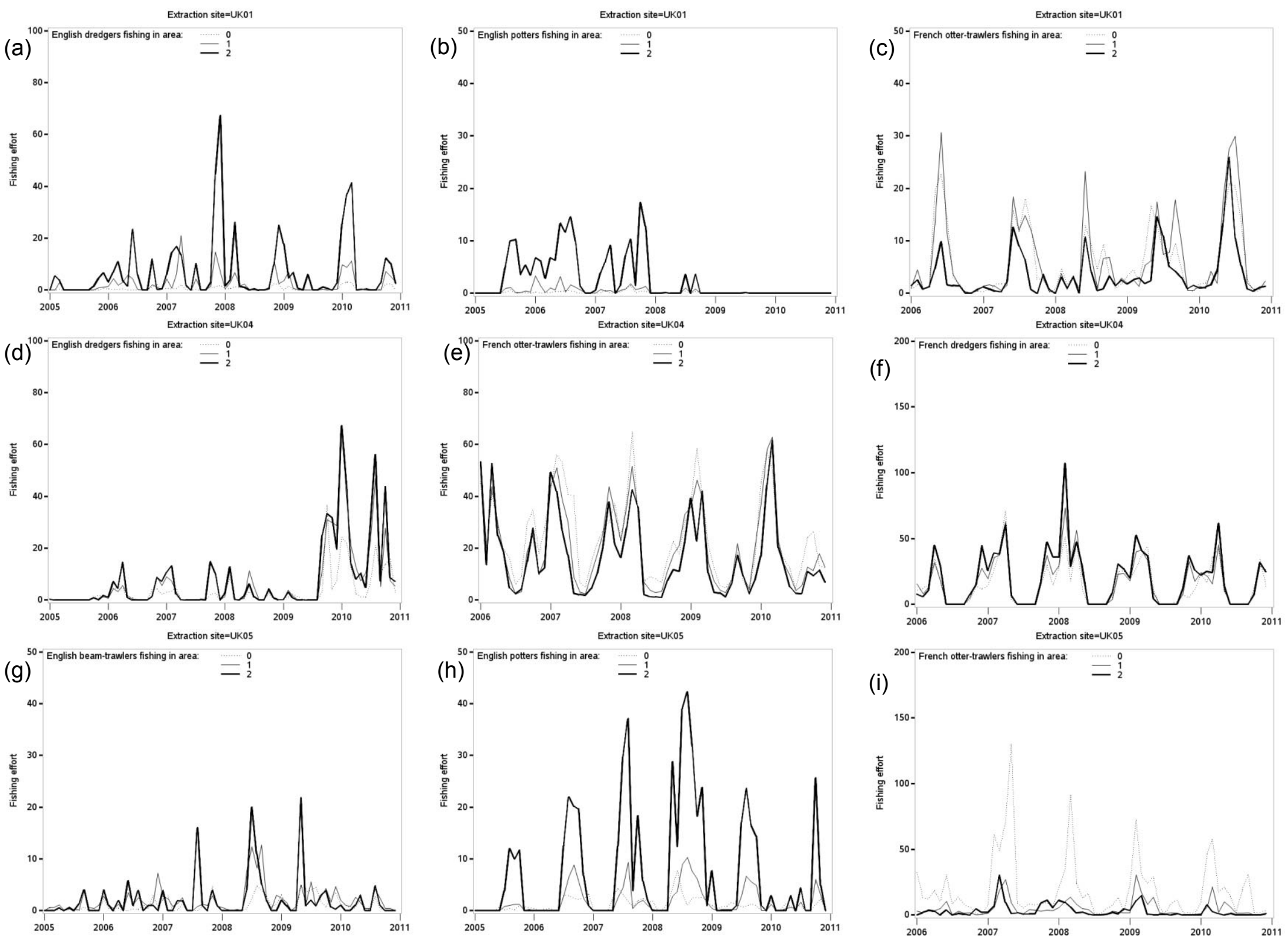

(f)
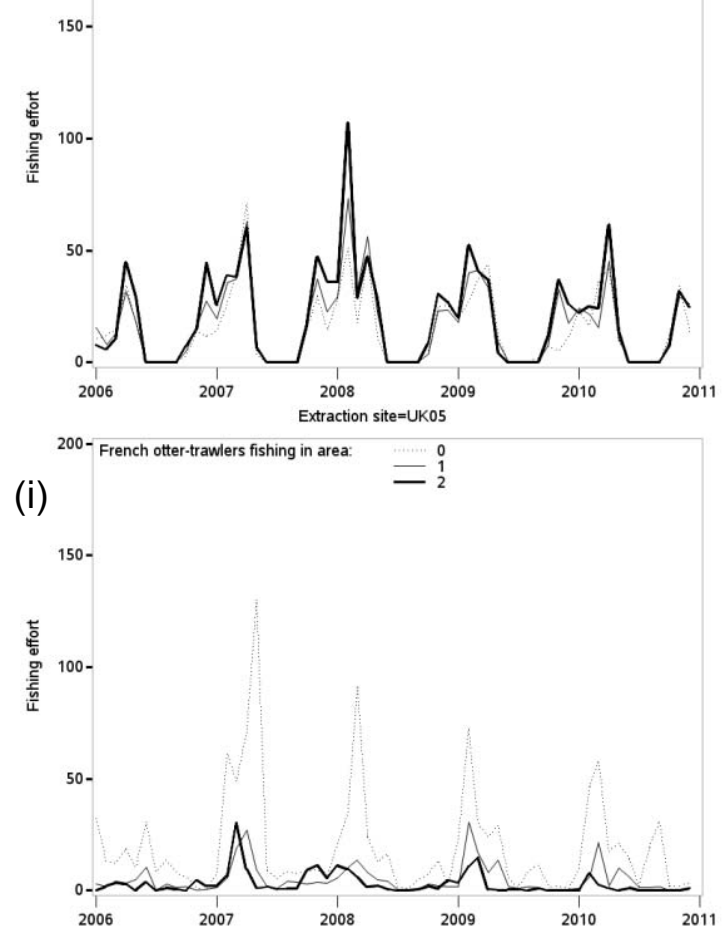
Figure 5.
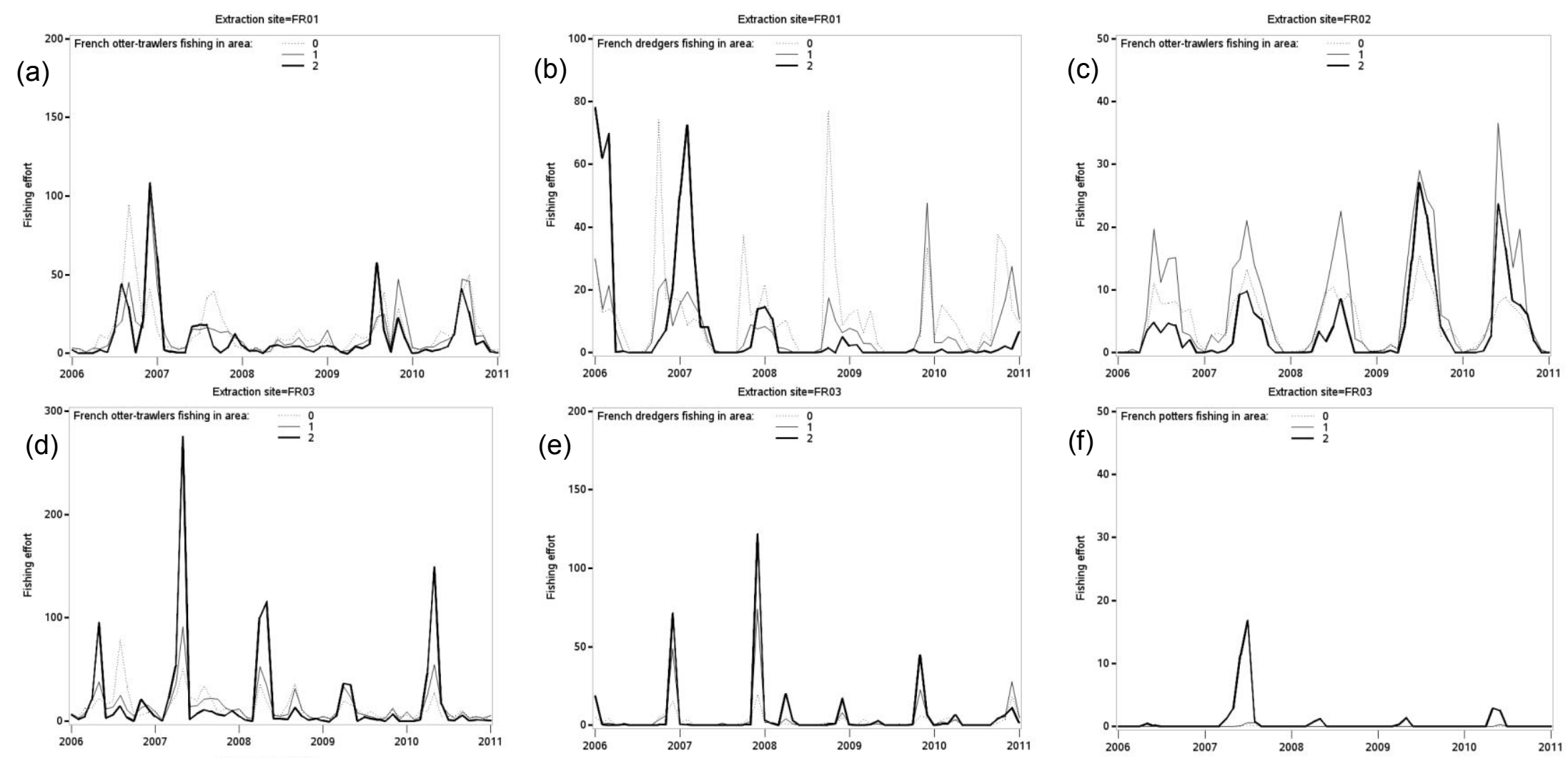

(e) ${ }^{200-\text { French dredgers fssing in area }}=\stackrel{0}{1}$
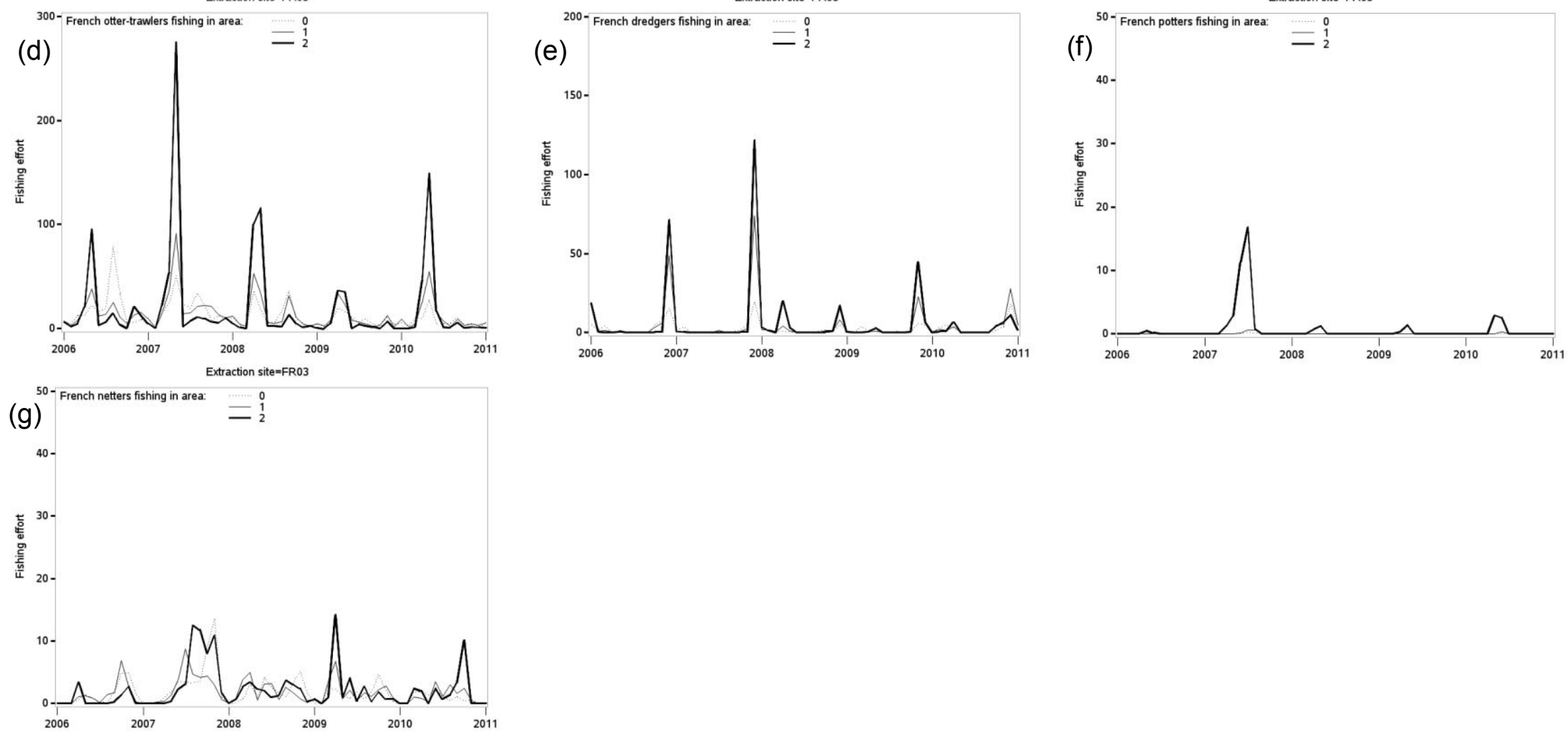
Figure 6.
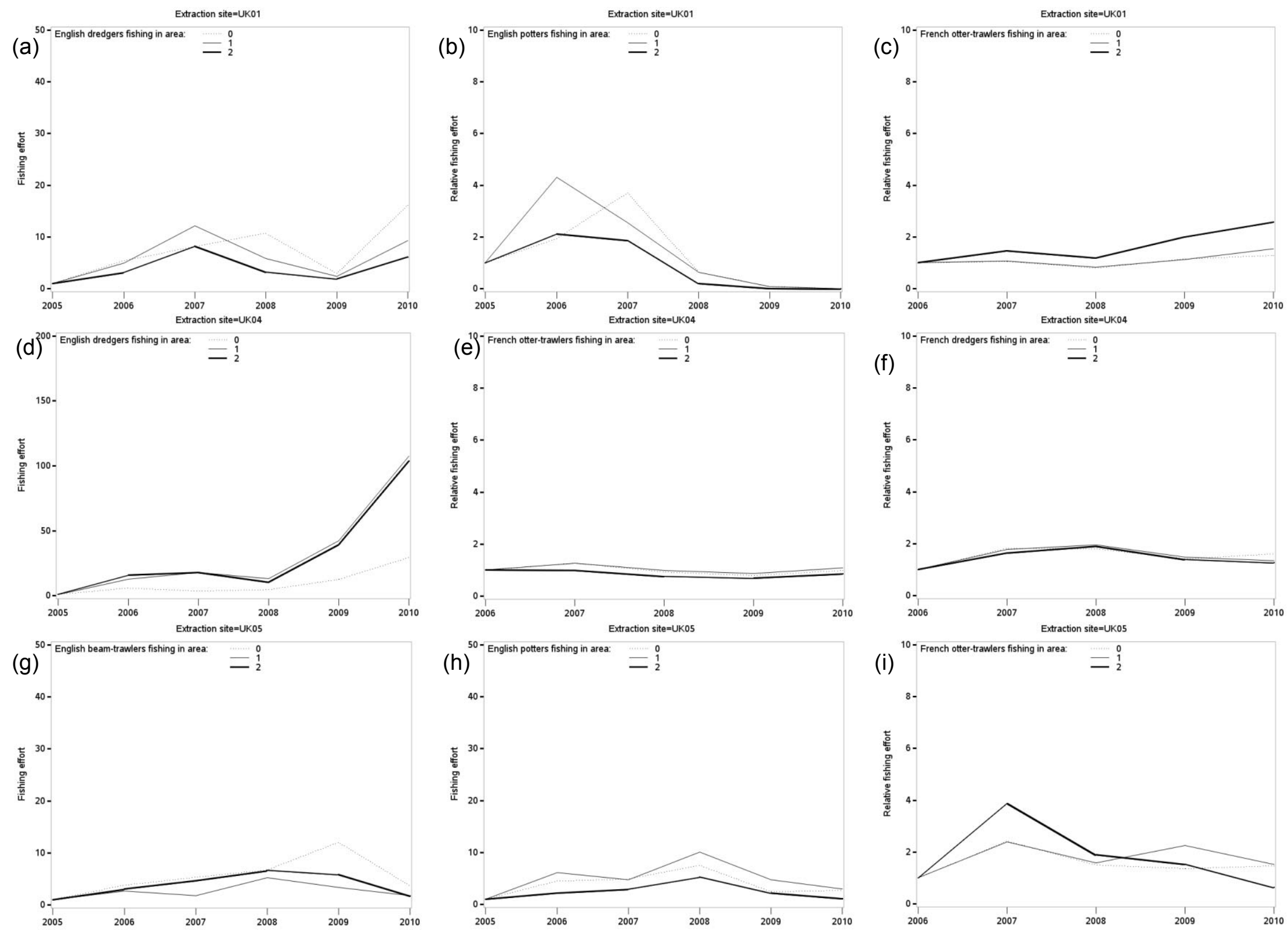
Figure 7.
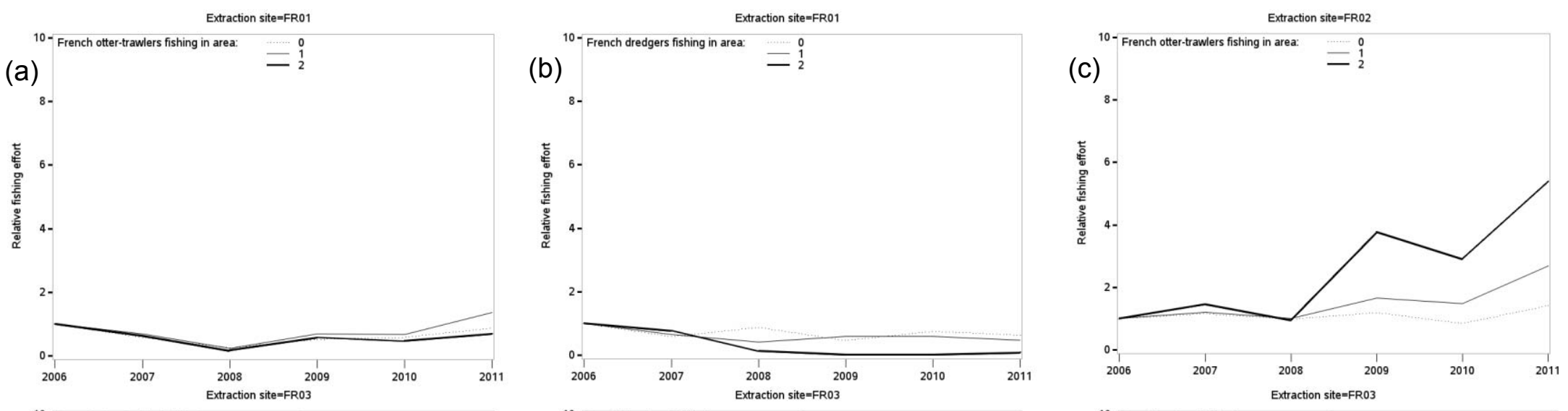

(d)

(e)

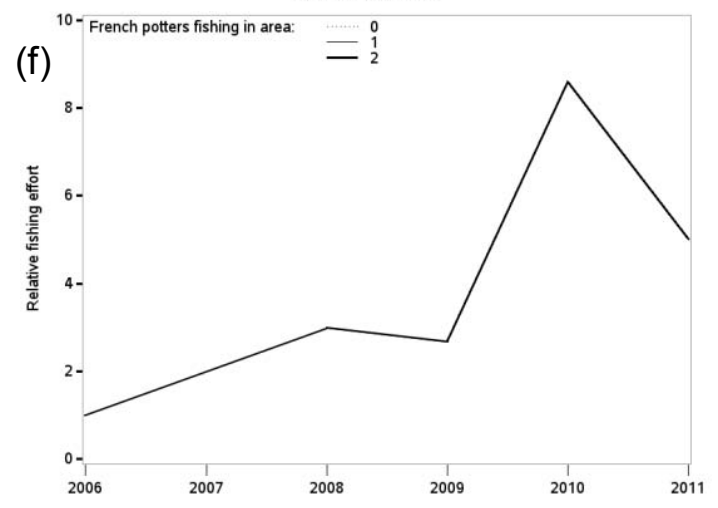

(g)
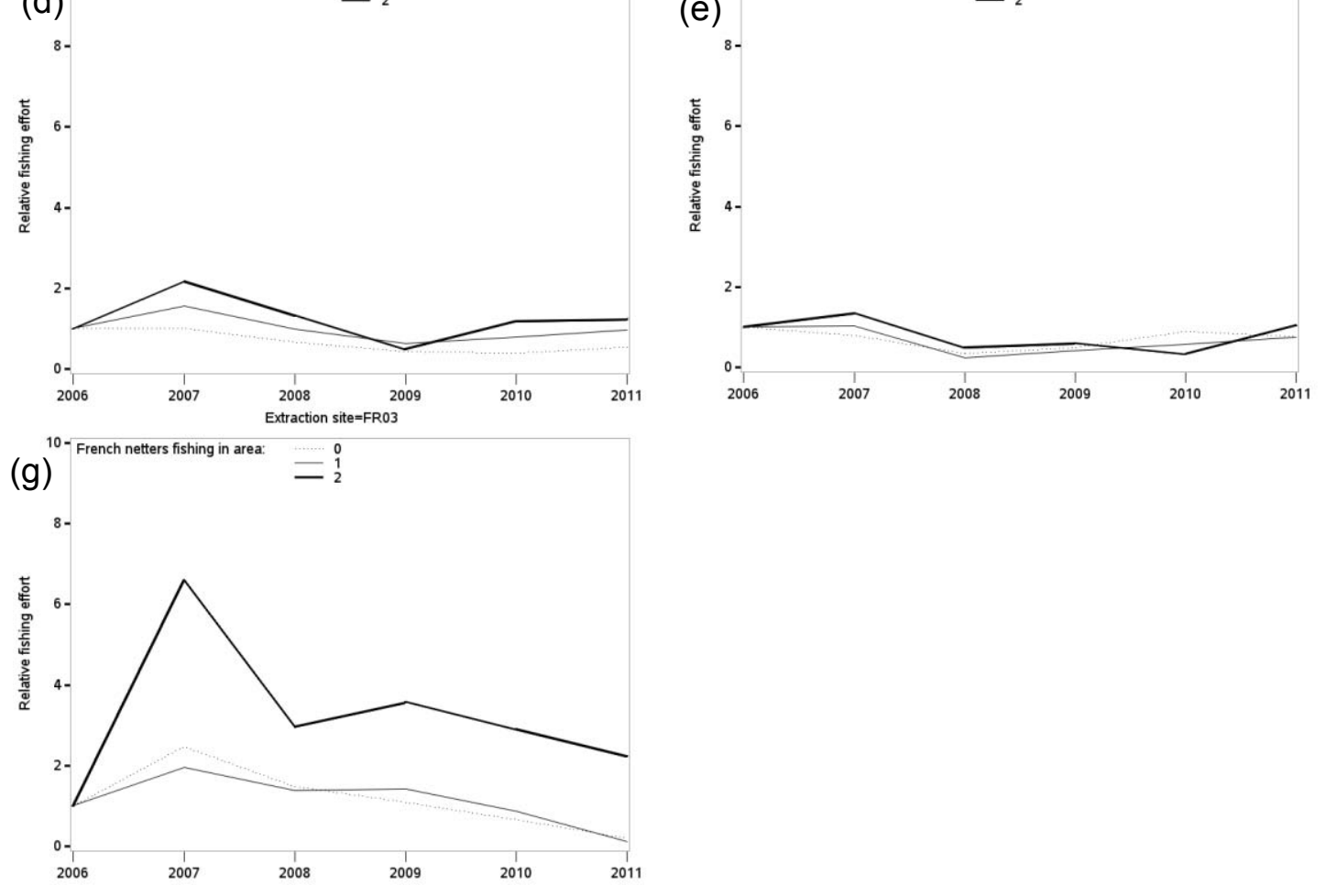